\title{
PENGEMBANGAN PEMBELAJARAN ERA POST MODERN MENUJU KETERCAPAIAN KEMAMPUAN MATEMATIS SISWA
}

\author{
Oleh: \\ Marchasan, Lexbin \\ Pendidikan Matematika STKIP Siliwangi Bandung \\ marchasanlexbin@yahoo.com
}

\begin{abstract}
ABSTRAK
Masalah pendidikan saat ini adalah masalah berpendidikan kelangsungan hidup masa depan. Jadi kegagalan dalam mencapai tujuan pendidikan dan pembelajaran matematika pada khususnya, juga akan memberikan kontribusi atau menentukan kelangsungan hidup bangsa ke depan. Selain menunjukkan belajar fakta matematika di sekolah belum dapat menuju ke arah tercapainya tujuan pendidikan. Menafsirkan hal tersebut, sikap yang benar adalah optimalisasi sikap profesional guru matematika, antara lain untuk mengembangkan pembelajaran melalui rencana pembelajaran dengan mempertimbangkan tujuan yang ingin dicapai atau sejalan dengan amanat kurikulum, bahan ajar, karakteristik peserta didik dan kemudian terintegrasi dengan makna belajar siswa sebagai kegiatan berpikir (cognition activities). Dan belajar membangun sifat siswa memahami konsep materi (konstruktivism) dari masalah yang diketahui siswa (kontekstual), solusi langkah-langkah panduan pada masalah terstruktur, selain guru intervensi interaktif dan rasa, yang memungkinkan setiap pembelajaran matematika telah selesai untuk masing-masing urutan bahan ajar yang dapat memberikan kepada setiap siswa untuk mencapai keterampilan matematika minimal sebagaimana diamanatkan oleh kurikulum pendidikan nasional.
\end{abstract}

Kata Kunci : tujuan pendidikan, pengembangan pembelajaran matematika

\begin{abstract}
The problem of education today is the problem of educated future viability. So the failure in achieving the goals of education and learning of mathematics in particular, will also contribute to or determine the viability of the nation forward. Moreover showed learning math facts at school yet to even just towards the achievement of educational goals. Interpret this, the right attitude is the optimization of the professionalism of teachers of mathematics, among others, to develop learning through the lesson plan by considering the goals you want or be achieved or in line with the mandate of the curriculum, teaching materials, characteristic of the learner and then integrated with the meaning of student learning as the activity of thinking (activities cognition). And learning the nature of students understanding of the concept of constructed material (constructivist) of the known issues students (contextual) guided steps solution on structured problems, in addition to the intervention teachers interactively and taste, allowing every mathematics learning has been completed for each sequence of teaching materials can deliver every student achieve minimal mathematical skills as mandated by the national education curriculum.
\end{abstract}

Keywords : Educational goals, the development of learning mathematics. 


\section{PENDAHULUAN}

Saat ini adalah era pasca modern. Ungkapan biasa 'Era Pasca Modern'. Ungkapan yang familiar, karena dalam keseharian kita telah terbiasa menggunakan produk iptek dalam upaya memenuhi berbagai kebutuhan. Kemudian terhenyak tapi menarik, saat ungkapan ini dikaitkan dengan pencapaian tujuan pendidikan. Karena dalam konteks ini ada pertanyaan klasik, "bagaimana dengan pendidikan dan pencapaian tujuannya di era pasca modern ".

Sejalan judul dan tujuan penulisan, uraian terbatas untuk melihat pentingnya pengembangan pembelajaran dalam menghantar setiap siswa mencapai tujuan pembelajaran. Sehingga uraian selanjutnya fokus pada kajian pengembangan pembelajaran matematika pada satu sekuen materi ajar menuju pencapaian kemampuan matematis siswa.

Hal ini dipandang penting karena adanya amanah kurikulum pendidikan nasional, yang mensyaratkan agar setiap pembelajaran matematika dapat menghantar setiap siswa pada pencapaian kemampuan pemahaman, kemampuan komunikasi hingga kemampuan pemecahan masalah. Sejalan hal itu setiap individu siswa adalah khas/unik dengan stile learning yang juga khas, berada pada sistem pengajaran yang klasikal, individu yang sedang berkembang dalam samudra stimulus dan materi ajar matematika merupakan materi yang sulit dipelajari dan diajarkan, permasalahan pembelajaran menjadi bertambah kompleks. Inilah tantangan guru dalam mencapai tujuan pembelajaran.

Permasalahan klasik dalam pembelajaran matematika sekolah tersebut, nampak sangat sederhana, tetapi mengelitik. Apalagi bila mengingat ungkapan berikut "Seorang dokter mengobati pasiennya kemudian tak sembuh dan bahkan mati disikapi dengan pernyataan kehendak Tuhan, seorang lawyer membela kliennya dan putusan hakim dipenjara seperti yang didakwakan Jaksa disikapi dengan pernyataan memang terbukti bersalah, seorang ekonom yang juga seorang pengusaha ternyata merugi dan usahanya nyaris bangkrut disikapi dengan ya lagi krisis". Kemudian, bagaimana bila kegagalan terjadi pada seorang guru matematika?, padahal guru telah berusaha mengajar dengan baik, siswa telah hadir disetiap pembelajaran, mengerjakan tugas mengikuti ulangan harian, bahkan sampai ulangan sumatif dan seterusnya.

Bagi yang berprofesi sebagai seorang guru; jangankan siswanya tidak lulus atau tidak naik kelas, sebatas tidak mencapai KKM disikapi dengan pernyataan tak etis, tak seharunya. Dan bila pun keadaan ini dikonsultasikan pada Guru Besar bidang pendidikan matematika, maka pasti pernyataannya adalah "Siapa pun siswa, bila telah berada dihadapan kita, maka kita harus menjadikannya hebat sesuai dengan potensinya". 
Uraian di atas terlebih yang terakhir menghantar pada pemikiran tentang pengembangan pembelajaran matematika yang dapat menghantar pembelajar pada pencapaian kemampuan matematis pada setiap pertemuan untuk setiap sekuen materi ajar.

\section{PEMBAHASAN}

Fakta berikut adalah salah satu petunjuk akan pentingnya pengembangan pembelajaran, yang dikutip dari sumber pemerintah Balitbang Puskur Depdiknas (2007) dengan temuan tentang permasalahan berdasarkan identifikasi aspek dokumen standar isi (tabel 1), aspek silabus (tabel 2), dan aspek pelaksanaan kegiatan belajar mengajar (tabel 3) pada tingkat satuan pendidikan tingkat menengah atas atau jenjang SMA.

\section{Tabel 1}

Data hasil identifikasi berdasarkan aspek dokumen SI jenjang SMA

\begin{tabular}{|c|l|}
\hline No & \multicolumn{1}{|c|}{ Permasalahan } \\
\hline 1 & $\begin{array}{l}\text { Sebagian besar guru tidak memahami, karena kurang membaca dokumen, atau } \\
\text { bahkan tidak memiliki dokumen tentang standar isi }\end{array}$ \\
\hline 2 & $\begin{array}{l}\text { Materi pelajaran tidak tertampung oleh alokasi waktu pada struktur kurikulum di } \\
\text { kelas X, XI, dan XII IPA (kepadatan materi masih cukup tinggi) }\end{array}$ \\
\hline
\end{tabular}

Tabel 2

Data hasil identifikasi berdasarkan aspek silabus jenjang SMA

\begin{tabular}{|c|l|}
\hline No & \multicolumn{1}{|c|}{ Permasalahan } \\
\hline 1 & $\begin{array}{l}\text { Guru belum mampu menyusun silabus, dengan alasan yang sesuai dengan kondisi } \\
\text { sekolah, termasuk keseragaman dengan sekolah lain, banyak guru yang mendapat } \\
\text { silabus dari MGMP, download dari internet }\end{array}$ \\
\hline 2 & Pengembangan indikator yang tidak relevan \\
\hline 3 & Tidak operasional, hanya dijadikan sebagai pelengkap administrasi guru \\
\hline 4 & $\begin{array}{l}\text { Tidak ada kesesuaian antara yang tertulis dalam silabus dengan pengalaman belajar } \\
\text { dalam action di kelas. Contoh disebutkan dalam silabus pembelajaran diskusi tapi } \\
\text { ternyata di kelas tetap ceramah saja }\end{array}$ \\
\hline 5 & Dalam proses pembelajaran di kelas guru masih mengacu pada buku teks yang ada \\
\hline 6 & RPP yang disusun tidak operasional (hanya sebagai pelengkap administrasi guru) \\
\hline 7 & $\begin{array}{l}\text { Metode pembelajaran tidak sesuai dengan materi (kesulitan memlih metode yang } \\
\text { sesuai dengan materi) }\end{array}$ \\
\hline 8 & Soal ujian yang diujikan secara nasional melibihi kedalaman kompetensi dasar \\
\hline
\end{tabular}


Tabel 3

Data hasil identifikasi berdasarkan aspek pelaksanaan KBM jenjang SMA

\begin{tabular}{|c|l|}
\hline No & \multicolumn{1}{|c|}{ Permasalahan } \\
\hline 1 & $\begin{array}{l}\text { Pembelajaran di kelas masih banyak yang hanya berdasarkan materi pada buku } \\
\text { pegangan yang kadang tidak melihat lagi kompetensi dan indikator dalam silabus atau } \\
\text { RPP. Silabus hanya sekedar kelengkapan administrasi }\end{array}$ \\
\hline 2 & Pelaksanaan pembelajaran di kelas masih konvensional, standar proses belum ada \\
\hline 3 & Metode pembelajaran di kelas masih konvensional, standar proses belum ada \\
\hline 4 & KBM kurang mengaktifkan siswa, masih mengejar target materi \\
\hline 5 & $\begin{array}{l}\text { Aspek penilaian dan pelaporan selama ini "kognitif, afektif, psikomotorik" kurang } \\
\text { cocok untuk mata pelajaran matematika. Standar penilaian belum ada }\end{array}$ \\
\hline 6 & $\begin{array}{l}\text { Penilaian terkadang tidak mencakup seluruh indikator atau KD karena soal disusun } \\
\text { tanpa kisi-kisi }\end{array}$ \\
\hline 7 & $\begin{array}{l}\text { Sumber belajar umumnya dan buku pegangan, sangat terbatas menggunakan } \\
\text { teknologi dan lingkungan }\end{array}$ \\
\hline
\end{tabular}

Memaknai temuan, simpulan sederhana adalah wajar. Artinya wajar bila pembelajaran matematika belum memperlihatkan dampak positif, yang antara lain menghantar siswa pada kepemilikan kemampuan matematis, sehingga wajar pula bila tiba saat UN semua pihak terkait resah dan khawatir termasuk guru bidang studinya yang padahal langsung mengasuh siswa-siswanya mempersiapkan untuk itu dalam waktu yang tak sekejap.

Atau apakah karena siswanya tidak giat belajar akibat konsentrasinya habis untuk merespons setiap stimulus? Terkait ini ada ilustrasi berikut; Pesatnya kemajuan teknologi (komputer) yang sangat mempengaruhi kehidupan manusia, berperan dalam kemajuan ilmu pengetahuan, misalnya dalam pemeriksaan atau pengujian pembuktian matematis: meskipun pembuktian dapat dilakukan dengan kepastian, pembuktian dengan menggunakan komputer ternyata tidak merupakan "aplikasi" matematika yang sederhana, karena melibatkan negosiasi tentang apa yang termuat dalam pembuktian (MacKenzie, dalam Moslehian, 2000).

Ilustrasi di atas, bila digunakan untuk memandang pencapaian tujuan pendidikan atau pencapaian tujuan pembelajaran matematika dapat bermakna bahwa; banyak hal yang kita fahami dan itu benar, dan untuk hal yang kita anggap benar itu seyogyanya tidak dianggap sebagai kebenaran yang absolut. Tetapi dari kebenaran yang kita fahami, kita juga memberi ruang untuk melihat/tahu/bila mungkin menemukan kebenaran lain. Keberanian kita dalam memaknai perkembangan pendidikan dewasa ini, menuntun kita menelusuri kembali apa yang terjadi pada pemikiran-pemikiran (thinking) di masa lalu, dan apa pengaruh masa lalu pada masa sekarang dan masa yang akan datang. 
Sebagai penghantar, berikut adalah garis besar dari tiga mega-paradigma pemikiran di Barat yang dibedakan dalam Tabel 4 :

Tabel 4.

Tiga Mega-paradigma Pemikiran

\begin{tabular}{|c|c|c|c|}
\hline Aspek & Pra-modern & Modern & Post-modern \\
\hline Waktu & $\begin{array}{l}\text { Sampai abad 16-17, } \\
\text { ketika terjadi } \\
\text { revolusi industri }\end{array}$ & $\begin{array}{l}\text { Dari abad 16-17, sampai ke } \\
\text { awal abad } 20\end{array}$ & $\begin{array}{l}\text { Sejak awal abad ke } 20 \\
\text { sampai saat ini. }\end{array}$ \\
\hline Tokoh & Para ahli di Yunani & $\begin{array}{l}\text { Dari Copernicus, Galileo, } \\
\text { Newton, Descartes, sampai } \\
\text { Einstein. }\end{array}$ & $\begin{array}{l}\text { Derrida, Foucault, Rorty, } \\
\text { Doll, dll. }\end{array}$ \\
\hline Karakteristik & $\begin{array}{l}\text { - Suatu harmoni } \\
\text { kosmologis, yang } \\
\text { memuat suatu } \\
\text { keseimbangan } \\
\text { ekologis, } \\
\text { epistemologis, dan } \\
\text { metafisis } \\
\text { - Memelihara } \\
\text { keseimbangan } \\
\text { mutu yang } \\
\text { dikotomi } \\
\text { (baik/buruk, } \\
\text { benar/salah, } \\
\text { etis/tidak dst.) }\end{array}$ & $\begin{array}{l}\text { - Visi yang terbuka, tetapi } \\
\text { tertutup dalam level yang } \\
\text { lebih dalam, sehingga } \\
\text { stabil, uniform, terurut } \\
\text { linear, non-transferable. } \\
\text { - Penentuan sebab-akibat } \\
\text { ditentukan secara } \\
\text { matematis. }\end{array}$ & $\begin{array}{l}\text { - Tidak ada kebenaran } \\
\text { yang mutlak (mis. } 1+3 \\
\text { tidak selalu sama dengan } \\
3+1 \text { ), dan setiap insan } \\
\text { berhak untuk } \\
\text { memahami. } \\
\text { - Menekankan pada } \\
\text { kesadaran, kesetujuan, } \\
\text { berpikir dan kreativitas. }\end{array}$ \\
\hline $\begin{array}{l}\text { Pengetahuan/ } \\
\text { Pendidikan }\end{array}$ & $\begin{array}{l}\text { Seorang yang } \\
\text { terdidik dapat } \\
\text { menyelaraskan } \\
\text { dengan alam } \\
\text { semesta dan } \\
\text { tekanan-tekanan } \\
\text { yang muncul. }\end{array}$ & $\begin{array}{l}\text { - Pengetahuan ditemukan, } \\
\text { bukan diciptakan } \\
\text { (tertutup). } \\
\text { - Transfer informasi } \\
\text { - Metode ilmiah, sosiologi } \\
\text { dan psikologi lahir. } \\
\text { - Afektif (perasaan, intuisi, } \\
\text { pengalaman) bukan } \\
\text { sumber pengetahuan. IQ } \\
\text { sangat menentukan. } \\
\text { - } 3 \text { R (reading, ritting, } \\
\text { rithmetic) }\end{array}$ & 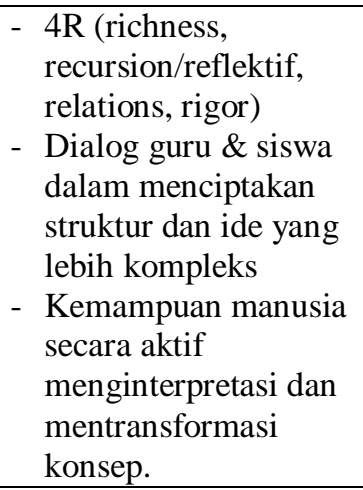 \\
\hline Matematika & $\begin{array}{l}\text { Empat adalah } \\
\text { bilangan sempurna } \\
\text { (contoh persegi, } \\
\text { dengan } \\
\text { keseimbangan antara } \\
\text { sisi dan sudutnya). }\end{array}$ & $\begin{array}{l}\text { Materi disajikan secara } \\
\text { terurut linear, seperti silabi } \\
\text { dan pembelajarannya. } \\
\text { Aspek yang tersembunyi } \\
\text { tapi dominan dalam } \\
\text { kurikulum dari kelas 1 SD } \\
\text { sampai PT. }\end{array}$ & $\begin{array}{l}\text { Lahirnya set kabur } \\
\text { (fuzzy), teori kacau } \\
\text { (chaos), teori } \\
\text { catastrophe, fraktal }\end{array}$ \\
\hline
\end{tabular}

(adaptasi dari sumber: yang telah disarikan Doll (1993)) 
Pemikiran dalam pra-modern tidak dibahas di sini. Tetapi dalam era transisi dari modernisme ke post-modernisme dikenal tokoh-tokoh seperti Jean Piaget (dengan model ekuilibrium: asimilasi dan akomodasi), Jerome Bruner (dengan social reciprocity-nya, yang juga dikenal oleh Lev Vygotsky dalam interaksi sosialnya), John Dewey (dengan berpikir reflektifnya), dan Alfred North Whitehead (dengan ritme pendidikannya: play - precision/mastery generalization/abstraction).

Secara umum, dalam dunia pendidikan khususnya, pemikiran tokoh-tokoh ini sangat berpengaruh untuk perkembangan paradigma dewasa ini. Kunci untuk lebih memahami pendidikan dalam era post-modern adalah konstruktivisme, karena itu konstruktivisme menjadi teori belajar yang mendasari pendidikan dalam postmodern. Dengan ide dasarnya, semua pengetahuan diinvensi atau seperti yang dikatakan Piaget "Knowledge is actively constructed by the learner, not passively received from the environment" (Dougiamas, 1998).

Pengetahuan tidak ditemukan, seperti yang diklaim oleh para modernis. Dengan kata lain, ide-ide tentang apa yang diajarkan oleh pengajar, dan apa yang dipelajari siswa tidak berkorespondensi dengan "realitas", tetapi benar-benar merupakan konstruksi pikiran manusia. Pengetahuan, ide-ide, dan bahasa diciptakan oleh manusia, bukan karena "benar", tetapi lebih karena bermanfaaat.

Sehingga akan tepat bila proses belajar melibatkan siswa untuk mencari makna, dan pengajar mempelajari cara bagaimana siswa mencari dan memahami makna. Hal ini sejalan dengan yang dikemukakan Geoghegan (2005) belajar dan mengajar menjadi fenomena yang refleksif, berdasarkan inter-koneksi antara pengajar dan siswa yang saling menjadi ko-instruktur dalam mencari dan memahami makna. Pendapat dimaksud mengandung makna bahwa dunia sosial dari seorang individu meliputi orang-orang yang langsung mempengaruhinya, seperti pengajar, teman, administrator, dan partisipan dalam semua bentuk aktivitas. Dan hal ini sejalan dengan pemikiran Vygotsky (1978), seorang ahli teori dalam psikologi yang memfokuskan pada peran masyarakat dalam perkembangan seseorang.

Dalam pandangan konstruktivisme sosial, matematika dilihat sebagai suatu konstruksi sosial. Pendidikan matematika dipandang sebagai suatu aktivitas yang sense-making: Siswa merekonstruksi secara sosial pengetahuan yang telah dimilikinya, dan dengan pengajar sebagai fasilitator, dan dengan teman sebaya sebagai lawan berdiskusi, ia mengkonstruksi pengetahuan baru.

Proses ini serupa dengan apa yang disebut enkulturalisasi (Schoenfeld, 1992) dan sosialisasi (Resnick, dalam Neyland, 1996), dengan kelompok siswa sebagai komunitas matematis pemula, dikulturisasi menuju komunitas matematis yang ahli. Pengajar tentu bertanggungjawab dalam membantu proses ini, dan bertindak sebagai agen dari pembaharuan kultural. Komunitas matematis yang menuju kriteria ahli ini 
diharapkan menjadi lebih dari sekedar matematikawan akademis, dengan cara mengembangkan kompetensi dan konsep matematika mereka.

Siswa sebagai individu akan aktif terlibat dalam membangun makna, dan pengajar akan mencari apa yang dapat siswa lakukan, seperti menganalisis, menginvestigasi, mengkolaborasi, memvalidasi, berbagi, dan membangun, berdasarkan apa yang mereka sudah tahu. Atau tidak hanya sekedar meniru fakta, keterampilan, dan proses. Proses ini melibatkan mempelajari konsep, orientasi, nilai, dan proses dari komunitas ini. Karena matematika dipresentasikan sebagai suatu jaringan dari pengetahuan, dan sebagai suatu aktifitas pemecahan masalah, problem posing, dan investigasi, dengan harapan siswa dapat membangun suatu pemahaman baru.

Siswa akan merefleksikan pengalaman matematis mereka, berperan dalam memvalidasi ide matematis, membentuk struktur-struktur pengetahuan yang dipelajari, sebagai bagian dari membangun kerangka referensi pengetahuan mereka.

Pembentukan nilai-nilai dasar kehidupan sosial dari komunitas kelompok juga diharapkan akan terbentuk dalam diri siswa, dengan lebih memahami dalam memposisikan matematika dalam suatu masyarakat, yang akan bermanfaat kelak. Yang bila memungkinkan sebagai tambahan, penggunaan teknologi yang canggih (seperti komputer) tentu membantu proses ini, disamping mereduksi waktu untuk prosedur matematika yang rutin, juga sebagai alat untuk menggali ide-ide.

Untuk melakukan ini secara efektif, pengajar perlu belajar dan meneliti, tanggap terhadap perspektif, pendekatan, perilaku, dan proses komunitas ini, berusaha keras untuk meningkatkan kesadaran dari lingkungan dan partisipan, menyesuaikan tindakannya secara kontinu dengan melibatkan siswa dalam pembelajaran, dengan menggunakan konstruktivisme sebagai rujukan.

Salomon dan Perkins (dalam Dougiamas, 1998) menyarankan bahwa 'perolehan dan 'partisipasi' dalam pembelajaran saling berelasi dan berinteraksi dalam cara yang sinergik. Mereka memodelkan entiti sosial sebagai seorang individu (misalkan suatu tim sepakbola, bisnis, atau keluarga), dan membandingkannya dengan pembelajaran individual dalam suatu setting sosial, dan mengindentifikasi tiga jenis utama dari relasi di atas:

1. Pembelajaran individual dapat lebih baik atau kurang baik daripada pembelajaran yang dimediasi secara sosial.

2. Individu dapat berpartisipasi dalam pembelajaran kolektif, kadang-kadang dengan apa yang dipelajari terdistribusi melalui kolektif, lebih dari pada dalam pikiran setiap individu.

3. Aspek individual dan sosial dari pembelajaran dapat berinteraksi dengan saling memperkuat dalam suatu 'hubungan spiral resiprokal'. 
Strategi mengajar yang merujuk ke konstruktivisme ;memuat pengajaran dalam konteks, secara personal dapat bermakna bagi siswa, dapat bernegosiasi sebagai makna kebersamaan, berdiskusi, berkolaborasi dalam kelompok kecil, dan menilai aktivitas yang bermakna, melalui jawaban yang benar (Wood, et al., 1995). Rujuk dengan produk pikir terurai dimaksud, penyusunan kurikulum tingkat satuan pendidikan, dikoordinasi dan disupervisi oleh dinas pendidikan provinsi, dan berpedoman pada Standar Isi dan Standar Kompetensi Lulusan serta panduan penyususnan kurikulum yang disusun oleh BSNP. Dan kurikulum ini dikembangkan berdasarkan prinsip-prinsip berikut:

i) Berpusat pada potensi, perkembangan, kebutuhan, dan kepentingan peserta didik dan lingkungannya.

ii) Beragam dan terpadu.

iii) Tanggap terhadap perkembangan ilmu pengetahuan, teknologi dan seni.

iv) Relevan dengan kebutuhan kehidupan.

v) Menyeluruh dan berkesinambungan.

vi) Belajar sepanjang hayat.

vii) Seimbang antara kepentingan nasional dan kepentingan daerah.

Dan sejalah dengan prinsip pengembangan kurikulun dimaksud, langkah awal sebelum guru melaksanakan pembelajaran di kelas adalah:

a) Menganalisis kurikulum.

Dalam hal ini diberikan contoh, analisis materi kelas VIII tentang lingkaran, yang telah dideskripsikan sebagai berikut :

Standar kompetensi : Geometri dan pengukuran

4. Menentukan unsur, bagian lingkaran serta ukurannya.

Kompetensi dasar : 4.2 Menghitung keliling dan luas lingkaran

Materi pokok : Lingkaran

Indikator : : Menghitung luas daerah lingkaran

Konsep matematika (uraian materi) yang harus dipelajari antara lain:

- Unsur-unsur dan bagian-bagian lingkaran: pusat lingkaran, jari-jari, diameter, busur, talibusur, juring dan tembereng.

- Menentukan nilai phi

- Menentukan rumus keliling dan luas lingkaran.

b) Identifikasi Masalah

Belajar bermakna adalah proses belajar dimana informasi atau pengetahuan baru dihubungkan dengan struktur yang sudah dipunyai seseorang yang sedang belajar.

Berikut diberikan contoh dalam materi lingkaran dengan masalah yang memerlukan penalaran dan pemahaman konsep, misalkan pada soal menentukan luas daerah lingkaran dengan harus mencari hal-hal yang diperlukan sebelumnya. 
Contoh: Perhatikan gambar di bawah! Tiga lingkaran berjari-jari $2 \mathrm{~cm}$. Hitunglah seluruh luas daerah yang diarsir

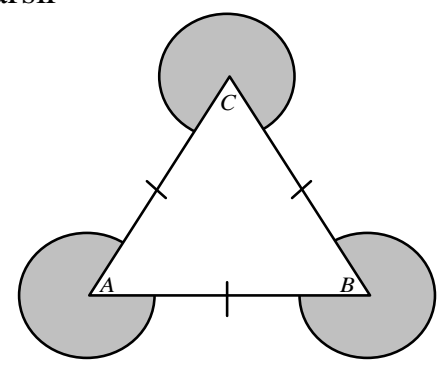

Siswa biasanya mengalami kesulitan dalam menyelesaikan masalah non rutin terbuka yang melibatkan penalaran dan pemahaman konsep. Studi yang dilakukan Shannon dan Zawojewski ( dalam Herman : 2006. 54) menunjukan akan sulitnya memberikan tugas pemecahan masalah yang disajikan tanpa petunjuk (hint) atau langkah-langkah pemgerjaannya.

Sebab untuk menghadapi masalah yang seperti di atas diperlukan penalaran dan penguasaan konsep yang baik. Untuk melatih penalaran dan pemahaman konsep yang baik diberikan tugas-tugas yang berupa latihan soal dengan pertanyaanpertanyaan terstruktur. Pertanyaan terstruktur ialah pertanyaan-pertanyaan yang disajikan melalui submasalah-submasalah atau subpertanya-an-subpertanyaan yang membantu untuk mengarahkan siswa kepada jawaban akhir.

Dari contoh soal serupa di atas: Perhatikan gambar di bawah! Tiga lingkaran berjarijari $2 \mathrm{~cm}$. Hitunglah seluruh luas daerah yang diarsir seperti nampak pada gambar di bawah berikut:

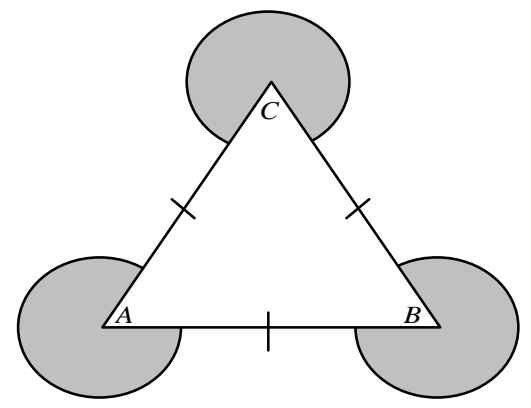

Maka untuk menuntun berpikir siswa dapat di buat pertanyaan pertanyaan terstuktur dengan berpikir mundur dari petanyaan yang ditanyakan menuju ke soal yang diketahui.

Dari soal di atas untuk mencari luas yang diarsir; dicari dulu luas satu lingkaran yang diarsir, untuk mencari luas satu lingkaran yang di arsir dicari dulu besar sudut 
pusat lingkaran yang di arsir, untuk mencari besar sudut lingkaran yang diarsir dicari dulu besar sudut segitiga sama sisi. Jadi subpertanyaan-subpertanyaan yang harus ditanyakan adalah: (1) Tentukan besar sudut dalam segitiga sama sisi ABC? (2) Tentukan besar sudut pusat satu lingkaran yang diarsir? (3) Tentukan luas satu lingkaran yang diarsir? (4) Tentukan luas daerah yang diarsir seluruhnya?

Dengan pertanyaan-pertanyaan terstruktur yang merupakan subpertanyaansubpertanyaan diharapkan siswa terbiasa dalam menyelesaikan masalah yang memerlukan penalaran dan pemahaman konsep dengan alur penyelesaian dan langkah-langkahnya, sehingga jika menghadapi soal yang seperti demikian siswa dapat menyelesaikan dengan membuat subpertanyaan-subpertanyaan sendiri.

Hal seperti terurai di atas, hendaknya merupakan masalah yang harus diselesaikan siswa dalam proses pembelajaran, yang dituangkan dalan lembar aktivitas siswa dengan mencerminkan karakteristik pembelajaran yang digunakan dan rujuk dengan tujuan dan kemampuan math yang ingin dicapai. Padangan dan pemahaman dalam memadukan model atau metode atau pendekatan yang akan digunakannya hendaknya disertai dengan pengetahuan atau perkiraan kondisi pembelajar dan karakteristik materi. Hal-hal tersebut harus menjadi rujukan mendasar dalam membuat perencanaan pembelajaran disertai upaya mengitegrasikannya pada pencapaian tujuan pembelajaran.

Jadi rambu dasar untuk langkah-langkah penyususunan secara umum adalah keharusan akan adanya korelasi dengan tujuan yang ingin dicapai dan kemampuan math yang harus dicapai siswa. Kemudian secara khusus; terkait dengan karakteristik pembelajaran yang akan dikenakan pada siswa yang harus didukung lembar aktivitas siswa (LAS) selaras keperluan, hingga penyusunan instrumen untuk mengetahui ketercapaian tujuan ( kemampuan math siswa)

Berikut satu contoh Rencana Pembelajaran (RPP) dengan pendekatan Penemuan Terbimbing (karakteristik tak diungkap di sini), dan lembar aktivitas siswa selaras dengan tujuan "menghantar setiap siswa pada pencapaian kemampuan pemahaman matematis (indikator dan instrumen tak diungkap di sini)

\section{RENCANA PEMBELAJARAN (Pertemuan Ke-1)}

$\begin{array}{ll}\text { Mata Pelajaran } & \text { : Matematika } \\ \text { Kelas / Semester } & : \text { XI / I } \\ \text { Waktu } & : 3 \times 45 \text { menit } \\ \text { Jumlah Pertemuan } & : 1 \text { pertemuan }\end{array}$

A. Standar Kompetensi

Memahami konsep peluang dan menemukan solusi atas masalah terkait 


\section{B. Kompetensi Dasar}

Siswa dapat merumuskan dan mengaplikasikan kaidah pencacahan dan aturan permutasi dalam pemecahan masalah

C. Indikator

1. Menentukan aturan pengisian tempat

2. Menentukan faktorial suatu bilangan asli

3. Mengaplikasikan aturan permutasi

D. Tujuan Pembelajaran

Setelah pembelajaran diharapkan siswa dapat:

1. Menjelaskan pengertian peluang

2. Menjelaskan pengertian permutasi

E. Materi Pembelajaran

(1) Aturan pengisian tempat (2) Faktorial bilangan asli (3) Permutasi dari unsurunsur yang berbeda (4) Permutasi dari unsur-unsur yang berbeda

F. Sumber Pembelajaran

Lembar Aktivitas Siswa dan Buku Siswa

G. Kegiatan Pembelajaran

Model Pembelajaran : Belajar dalam Kelompok Kecil

Metode

: Diskusi, Tanyajawab dan Pemberian Tugas

Pendekatan

: Penemuan Terbimbing

Prosedur pembelajaran terurai pada Tabel :

\begin{tabular}{|c|c|c|}
\hline No & Kegiatan & Waktu \\
\hline 1 & $\begin{array}{l}\text { Pendahuluan } \\
\text { Guru memotivasi siswa dengan cara menyampaikan } \\
\text { pentingnya pokok bahasan permutasi yang berguna dalam } \\
\text { kehidupan sehari-hari, dengan cara memberikan ilustrasi } \\
\text { masalah }\end{array}$ & $\begin{array}{l}10 \\
\text { Menit }\end{array}$ \\
\hline 2. & $\begin{array}{l}\text { Kegiatan Inti } \\
\text { 1. Guru mengelompokan siswa menjadi beberapa kelompok, } \\
\text { terdiri dari } 4-5 \text { orang. Dalam setiap kelompok terdapat siswa yang } \\
\text { pandai, sedang, dan rendah. } \\
\text { 2. Guru membagikan LAS dan mengajukan contoh masalah } \\
\text { yang ada dan meminta siswa secara individu mempelajari } \\
\text { masalah tersebut. } \\
\text { 3. Siswa mendiskusikan masalah tersebut dalam kelompoknya } \\
\text { masing-masing. } \\
\text { 4. Guru memantau jalannya diskusi dan memberikan bimbingan }\end{array}$ & $\begin{array}{l}95 \\
\text { Menit }\end{array}$ \\
\hline
\end{tabular}




\begin{tabular}{|c|c|c|}
\hline & $\begin{array}{l}\text { secukupnya pada siswa jika masalah tersebut tidak dapat } \\
\text { dipecahkan dalam kelompoknya. } \\
\text { 5. Setiap kelompok menampilkan jawabannya di depan kelas dan } \\
\text { dibahas secara bersama-sama. Jika terdapat jawaban yang salah } \\
\text { maka diadakan tanyajawab dan guru mengarahkan menjadi } \\
\text { jawaban yang benar. }\end{array}$ & \\
\hline 3 & $\begin{array}{l}\text { Penutup } \\
\text { a. Reviuw } \\
\text { Guru menjelaskan kembali secara singkat tentang materi kaidah } \\
\text { pencacahan dan membimbing siswa untuk merangkumnya. } \\
\text { b. Siswa yang berkemampuan rendah/berkesulitan diberi tugas } \\
\text { tambahan atau sampai pemberian waktu tambahan di luar jam } \\
\text { mengajar } \\
\text { Kegiatan yang dilakukan adalah: } \\
\text { 1. Guru membangkitkan motivasi } \\
\text { 2. Pada tahapan selanjutnya untuk siswa yang mengalami } \\
\text { masalah dalam pemahaman konsep maka diberikan } \\
\text { penjelasan materi prasyarat. } \\
\text { 3. Guru mengawasi siswa mengerjakan soal-soal latihan } \\
\text { yang tersisa atau diadakan dan memeriksa hasil } \\
\text { pekerjaan siswa untuk menentukan kebenaran jawaban } \\
\text { siswa. Bagi siswa yang belum mengerti diberi } \\
\text { kesempatan untuk bertanya. } \\
\text { 4. Pada kegiatan penutup guru menyimpulkan materi yang } \\
\text { dipelajari dan konsep-konsep yang diperlukan dalam } \\
\text { menyelesaikan soal latihan tersebut. Kemudian kembali } \\
\text { menanamkan kembali semangat belajar yang tinggi } \\
\text { kepada siswa. } \\
\text { c. Penugasan Pekerjaan Rumah } \\
\text { Guru memberikan soal-soal latihan pekerjaan rumah untuk } \\
\text { dikerjakan secara individual. }\end{array}$ & $\begin{array}{l}30 \\
\text { menit }\end{array}$ \\
\hline
\end{tabular}

\section{Lembar Aktivitas Siswa ke-1 (contoh)}

\section{A. Aturan Pengisian Tempat Yang Tersedia.}

Dalam kehidupan sehari-hari sering kita mendapatkan permasalahan yang berhubungan dengan kemungkinan banyaknya cara yang dapat dipilih atau dilakukan dari suatu masalah yang harus segera di atasi.

Untuk lebih jelasnya, coba selesaikan permasalahan berikut.

\section{contoh 1 :}

Iwan pergi ke Toko untuk membeli pakaian yang terdiri dari 2 celana masingmasing berwarna hitam, dan biru, serta 4 baju masing-masing berwarna putih, kuning, merah dan ungu. Jika Iwan ingin mengkombinasikan pakaian yang telah 
dibeli tersebut terdapat berapa pasangan (susunan) baju dan celana yang dapat dipakai oleh Iwan?

\section{Pembahasan 1}

\section{Misalkan :}

warna celana $: \mathrm{H}=$ Hitam; $\mathrm{B}=$ Biru

warna baju $: \mathrm{P}=$ Putih, $\mathrm{K}=$ Kuning, $\mathrm{M}=$ Merah, $\mathrm{U}=$ Ungu

Kemudian selesaikan diagram pohon berikut untuk menemukan banyaknya kombinasi warna celana dan baju yang dapat pakai oleh Iwan

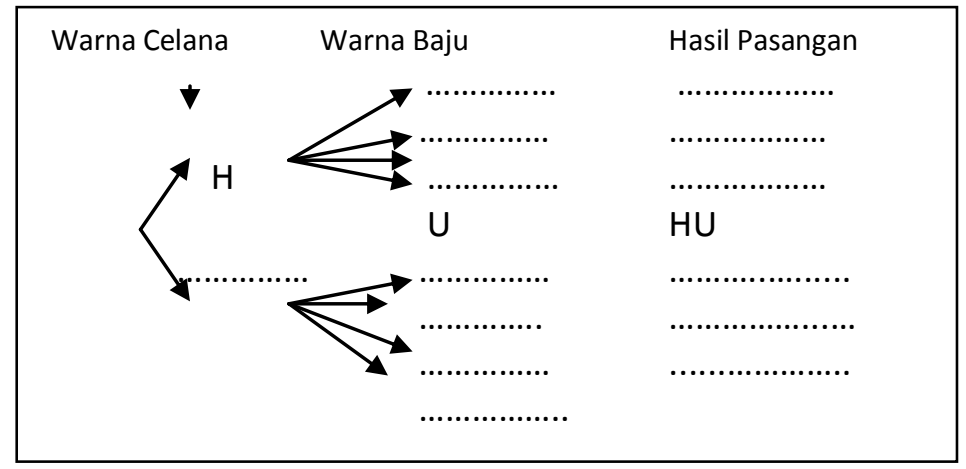

Simpulan apa yang didapat? Berapakah jumlah pasangan warna baju celana secara keseluruhan yang dapat dikenakan oleh Iwan?

Cara lain, gunakan tabel berikut agar kamu dapat menentukan jumlah pasangan celana dan baju yang dapat pakai oleh Iwan.

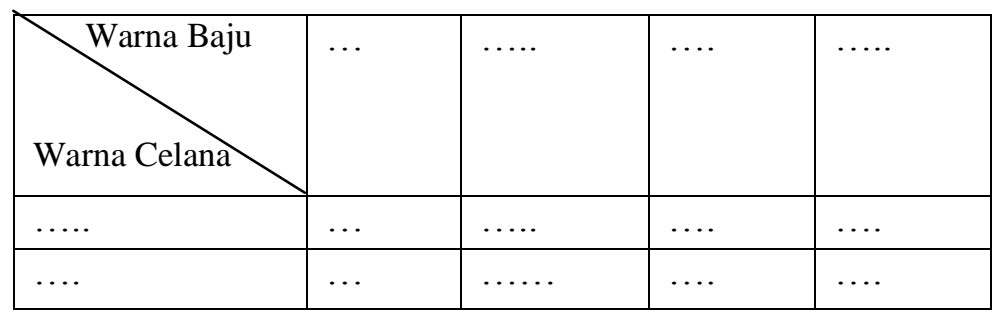

Dari tabel tersebut terdapat berapa pasangan baju dan celana yang dapat dipakai oleh Iwan?

Setelah menggunakan diagram pohon dan tabel. Coba gunakan pasangan terurut (produk kartesius), untuk menentukan jumlah kemungkinan pasangan celana dan baju yang dapat dikenakan oleh Iwan.

Coba kamu tuliskan himpunan pasangan terurut tersebut ! 
Berapakah jumlah unsur (anggota) dalam pasangan terurut tersebut ?....

Setelah kamu menggunakan ketiga cara di atas apakah mempunyai hasil yang sama? Dan apakah banyaknya cara untuk mengkombinasikan pasangan celana dan baju yang dapat dipakai oleh Iwan adalah $\ldots . . . .=$...cara?

\section{Soal Latihan :}

1. Untuk membantu kelancaran proses pembelajaran dalam kelas kamu akan dipilih seorang ketua, sekretaris dan bendahara dari 3 orang calon yang memenuhi syarat. Berapa banyak cara kamu dapat mengkombinasikan ketiga posisi tersebut?

2. Andi akan bepergian dari kota Bau-Bau (B) menuju Kolaka. Untuk sampai ke Kolaka dapat dilewati melalui kota Raha (R) dengan tiga jalan. Kemudian dari Kota Raha (R) menuju Kolaka (K) dapat ditempuh dengan 4 jalan.

(a). Gambarlah jaringan jalan yang menunjukkan hubungan kota Bau-Bau, Raha, dan Kolaka

(b) Berapakah banyaknya cara yang dapat dilalui oleh Andi untuk berpergian dari kota Bau-Bau menuju Kolaka.

3. Jika kejadian $\mathrm{M}$ dapat terjadi $\mathrm{x}$ cara dan kejadian $\mathrm{N}$ dapat terjadi $\mathrm{y}$ cara maka kedua kejadian dapat terjadi dalam ................cara

\section{B. Faktorial dari suatu Bilangan asli (langsung)}

Faktorial dari suatu bilangan asli didefinsikan sebagai berikut :

Untuk setiap bilangan asli $n$, didefinisikan :

$$
n !=1 \times 2 \times 3 \times 4 \times \ldots \times(n-2)(n-1) \times n
$$

Lambang atau notasi $\mathrm{n}$ ! dibaca sebagai $\mathrm{n}$ faktorial.

Didefinisikan pula bahwa :

$$
1 !=1 \text { dan } 0 !=1
$$

Dengan menggunakan definisi tersebut, faktorial suatu bilangan asli dapat ditentukan. Coba kamu selesaikan faktorial bilangan asli berikut ini :

$5 !=$ ; 6 ! = ; 7 =

\section{Permutasi dari unsur-unsur yang berbeda}

Masalah permutasi sering kita dapatkan dalam kehidupan sehari-hari.

Berikut ini merupakan contoh bagaimana menerapkan aturan permutasi.

\section{Contoh soal 2:}

Terdapat tiga buah angka 4, 5,dan 6. dari angka tersebut kita menyusun suatu bilangan yang terdiri dari 3 angka dengan bilangan-bilangan itu tidak mempunyai angka yang sama. Berapa jumlah susunan yang dapat dibentuk? Perlihatkan susunan bilangan yang dapat terbentuk dengan dua cara! 


\section{Pembahasan 2}

a)Jumlah susunan yang dapat dibentuk:

1. Angka ke-1 dalam susunan bilangan dapat dipilih ....... cara.

2. Angka ke-2 dalam susunan bilangan dapat dipilih .....cara.

3. Angka ke 3 dalam susunan bilangan dapat dipilih ... cara.

Dengan menggunakan aturan perkalian, banyaknya susunan yang mungkin itu seluruhnya: .................... =.....cara

\section{b) Susunan bilangan yang dapat dibentuk}

Terdapat dua cara untuk memperlihatkan kemungkinan susunan bilangan yang terbentuk yaitu:

\section{Cara I: Diagram pohon}

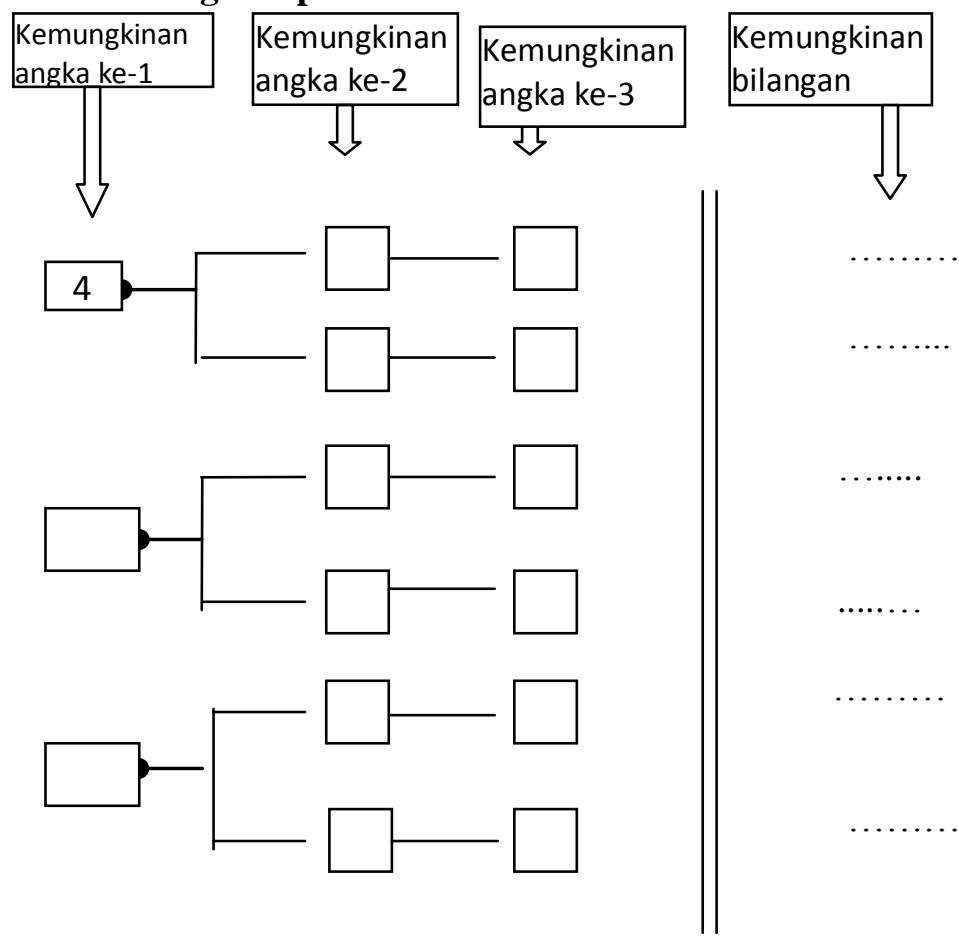

Perhatikan gambar di atas coba kamu isi kotak yang masing kosong dan kemudian tulislah kemungkinan susunan bilangan yang dapat dibentuk. Banyak cara untuk membuat susunan bilangan? 


\begin{tabular}{|l|l|l|c|}
\hline Posisi Angka ke-1 & $\begin{array}{l}\text { Posisi } \\
\text { Angka Ke-2 }\end{array}$ & $\begin{array}{l}\text { Posisi } \\
\text { Angka Ke-3 }\end{array}$ & $\begin{array}{l}\text { Susunan } \\
\text { Bilangan }\end{array}$ \\
\hline & $\ldots \ldots$ & $\ldots \ldots$ & $\ldots \ldots$ \\
\cline { 2 - 4 } & $\ldots \ldots$ & $\ldots \ldots$ & $\ldots \ldots$ \\
\hline & $\ldots \ldots$ & $\ldots \ldots$ & $\ldots \ldots$ \\
\cline { 2 - 4 } & $\ldots \ldots$ & $\ldots \ldots$ & $\ldots \ldots$ \\
\hline & $\ldots \ldots$ & $\ldots \ldots$ & $\ldots \ldots$ \\
\cline { 2 - 4 } & $\ldots \ldots$ & $\ldots \ldots$ & $\ldots \ldots$ \\
\hline
\end{tabular}

\section{Cara II: Menggunakan Tabel}

Susunan yang kamu peroleh seperti di atas disebut susunan unsur yang diambil dari .... unsur yang tersedia.

Berdasarkan contoh di atas maka dapat dibuat aturan umum berikut:

Jika terdapat $\mathrm{n}$ jenis unsur ditempatkan pada $\mathrm{n}$ buah tempat maka diperoleh formula: tempat ke-1 tempat ke-2 tempat ke-3....... tempat ke-n

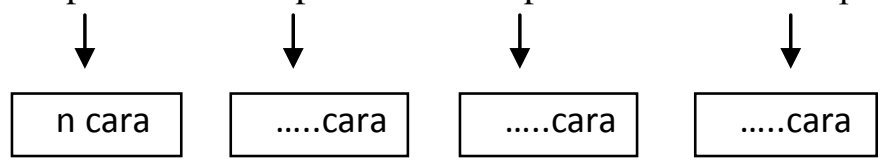

banyaknya cara menyusun adalah : $P_{n}^{n}=\mathrm{n} \times \ldots \mathrm{x} \ldots . . . \ldots \ldots$

$$
=\ldots . . \text { ! }
$$

\section{Contoh 3 :}

Misalkan terdapat empat angka yaitu 4,5,6 dan 7 akan disusun suatu bilangan yang terdiri dari dua angka dengan bilangan-bilangan itu tidak mempunyai angka yang sama, berapakah banyak susunan bilangan yang dapat dibentuk dan daftarkan susunan bilangan tersebut?

\section{Pembahasan 3:}

a) Banyaknya susunan bilangan yang dapat dibentuk adalah

b) Daftar semua susunan bilangan tersebut:

1) Dengan menggunakan diagram pohon:

2) Dengan menggunakan tabel: 
Dari contoh di atas nampak bahwa susunan yang kamu peroleh seperti di atas disebut permutasi ......... unsur yang diambil dari .... unsur yang tersedia. Untuk mempersingkat dapat ditulis:

$P_{2}^{4}=4 \times 3=\frac{4 !}{\ldots . . !}=\frac{4 !}{(\ldots . .-\ldots . .) !}=$

Berdasarkan deskripsi contoh di atas maka simpulan adalah:

Banyaknya permutasi .............unsur yang diambil dari unsur yang tersedia ditentukan oleh aturan:

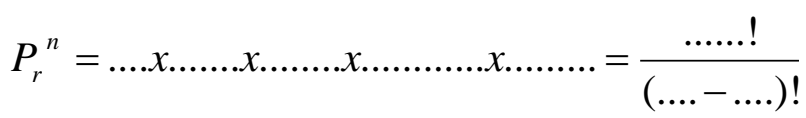

Setelah kamu menggunakan diagram pohon dan tabel untuk membuat kemungkinan susunan yang dapat dibentuk jawablah pertanyaan berikut:

1. Apakah bilangan yang terbentuk angkanya selalu berulang?

2. Apakah urutan angka yang terbentuk diperhatikan (misalnya apakah susunan $456=654) ? \ldots$

Berdasarkan deskripsi di atas coba kamu berikan definisi tentang permutasi sesuai dengan kata-katamu sendiri

\section{Permutasi yang Memuat Unsur yang Sama}

Pada pembicaraan sebelumnya permutasi yang ditekankan adalah banyaknya unsur yang tersedia memiliki unsur yang berbeda. Sekarang timbul pertanyaan bagaimana jika jumlah n unsur yang tersedia memiliki unsur yang sama?

\section{Contoh 3}

Misalnya terdapat susunan huruf "MAMA". Berapa banyak susunan huruf yang dapat disusun dari kata "MAMA"?

\section{Pembahasan 3}

1. Gunakan cara menyusun dengan menggunakan pendekatan unsur-unsurnya berbeda. Oleh karena itu kita dapat menggunakan indeks sehingga dapat diperoleh seperti kolom (1) pada tabel dibawah.

2. Karena $\mathbf{M}_{1}=\mathrm{M}_{2}$ dan $\mathrm{A}_{1}=\mathrm{A}_{2}$, maka berapa susunan yang mungkin? 


\begin{tabular}{|c|c|c|c|}
\hline $\begin{array}{l}\text { Susunan den } \\
\text { gan indeks }\end{array}$ & $\begin{array}{l}\text { Susunan tanpa } \\
\text { indeks } \\
\left(\mathrm{M}_{1}=\mathrm{M}_{2} ; \mathrm{A}_{1}=\mathrm{A}_{2}\right)\end{array}$ & $\begin{array}{l}\text { Susunan } \\
\text { dengan } \\
\text { indeks }\end{array}$ & $\begin{array}{l}\text { Susunan } \\
\text { indeks } \\
\left(\mathrm{M}_{1=} \mathrm{M}_{2 ;} \quad \mathrm{A}_{1=} \mathrm{A}_{2}\right)\end{array}$ \\
\hline $\begin{array}{llll}M_{1} & A_{1} & M_{2} & A_{2} \\
M_{1} & A_{2} & M_{2} & A_{1} \\
M_{2} & A_{2} & M_{1} & A_{1} \\
M_{2} & A_{1} & M_{1} & A_{2} \\
M_{1} & M_{2} & A_{1} & A_{2} \\
M_{1} & M_{2} & A_{2} & A_{1} \\
M_{2} & M_{1} & A_{2} & A_{1} \\
M_{2} & M_{1} & A_{1} & A_{2} \\
M_{1} & A_{1} & A_{2} & M_{2} \\
M_{1} & A_{2} & A_{1} & M_{2} \\
M_{2} & A_{1} & A_{2} & M_{1} \\
M_{2} & A_{2} & A_{1} & M_{1}\end{array}$ & ?............... & $\begin{array}{llll}A_{1} & A_{2} & M_{2} & M_{1} \\
A_{1} & A_{2} & M_{1} & M_{2} \\
A_{2} & A_{1} & M_{2} & M_{1} \\
A_{2} & A_{1} & M_{1} & M_{2} \\
A_{2} & M_{2} & M_{1} & A_{1} \\
A_{2} & M_{1} & M_{2} & A_{1} \\
A_{1} & M_{1} & M_{2} & A_{2} \\
A_{1} & M_{2} & M_{1} & A_{2} \\
A_{1} & M_{2} & A_{2} & M_{1} \\
A_{1} & M_{1} & A_{2} & M_{2} \\
A_{2} & M_{1} & A_{1} & M_{2} \\
A_{2} & M_{2} & A_{1} & M_{1}\end{array}$ & $\cdots$ \\
\hline
\end{tabular}

Pada kata MAMA terdapat 2 huruf A yang sama dan 2 huruf $M$ yang sama maka setiap pengaturan huruf A akan berulang sebanyak kali dan 2 huruf $\mathrm{M}$ akan berulang sebanyak...............kali, maka banyak susunan dari empat huruf yang tersedia dibagi dengan 2 × 2 . Jadi banyak susunan huruf yang dapat disusun dari kata "MAMA" $=\frac{\ldots \ldots \ldots !}{2 \times 2}=\frac{\ldots \ldots !}{\ldots ! x \ldots !}=\ldots .$.

Kerjakan contoh berikut:

1. Berapa banyak susunan huruf yang dapat disusun dari kata "ABA"?

2. Berapa banyak susunan huruf yang dapat disusun dari kata "PAPAKU"?

Berdasarkan deskripsi di atas maka coba buatlah kesimpulan secara umum tentang permutasi yang memuat beberapa unsur yang sama

\section{E. Penutup}

Kerjakan secara individu soal pekerjaan rumah berikut (rujukan, buku pegangan siswa) :

1. Sebuah organisasi terdiri atas 8 anggota putra dan 7 anggota putri. Akan dipilih 1 orang anggota putra dan 1 orang anggota putri. Berapakah banyaknya cara untuk memilih susunan pengurus dalam organisasi tersebut?

2. Sekarang coba kamu berikan beberapa contoh tentang permutasi dan bukan permutasi! 
3. Berapa banyak bilangan yang terdiri atas tiga angka yang dapat dibentuk dari angka-angka berikut:
a. $5,6,7$, dan 8
b. $1,2,3,4,5$, dan 6

4. Dalam sutau kelas terdapat 5 orang murid yang dajukan oleh temantemanmu untuk dipilih menjadi calon ketua OSIS dan sekretaris OSIS. Berapakah banyaknya susunan yang dapat dibuat untuik dipilih menjadi ketua dan sekretaris OSIS? Tunjukan susunan tersebut dengan dua cara!

5. Misalnya terdapat susunan huruf "KAKAK". Berapakah banyaknya susunan huruf yang dapat disusun dari kata "KAKAK"?

\section{SIMPULAN}

Landasan berpikir tentang pembelajaran di era post modern seperti saat ini adalah siswa menemukan kembali konsep materi melalui proses pembelajaran, sejalan dengan pemahaman bahwa belajar adalah aktivitas berpikir pembelajar. Konteks ini harus terakomodasi dalam pendekatan pembelajaran yang digunakan guru. Dan salah satu diantaranya diuraikan di atas (penemuan terbimbing) dengan karakteristik; bersifat kooperatif, berbasis masalah yang bersifat kontekstual disertai panduan bagi siswa untuk sampai pada menemukan kembali konsep materi ajar, interaktif dan intervensi guru yang terbatas.

Dengan dilaksanakannya pembelajaran seperti ini oleh guru matematika di dalam keseharian tugasnya, matematika yang sulit dipelajari dann sulit diajarkan akan dapat dipelajari siswa hingga yang bersangkutan sampai pada pencapaian kemampuan pemahaman matematis relevan dengan sekuen materi ajar.

Intinya, awali setiap pembelajaran dengan perencanaan melalui membuat rencana pengembangan pembelajaran, dan melaksanakannya dengan tepat benar. Anak didik pasti menjadi penerus yang handal.

\section{DAFTAR PUSTAKA}

Doll, W.E.,Jr. (1993). A Post-modernism Perspective on Curriculum. New York: Teachers College Press.

Dougiamas, M. (1998). A Journey into Constructivism. (Tidak dipublikasikan). Curtin University, Perth, Australia Barat. [Online]. Tersedia: http://dougiamas.com/writing/constructivism.html

Geoghegan, N. (2005). SEARCHING for Control in a Post-modern Mathematica classroom. The Mathematics Education into the 21st Century Project: Universiti Teknologi Malaysia. [Online]. Tersedia: http://math.unipa.it/ grim/21_project/21_malasya_2005 


\section{Infinitity}

Herman. (2006). Pembelajaran Berbasis Masalah untuk Meningkatkan Kemampuan Berpikir Matematik Tingkat Tinggi Siswa Sekolah Menengah Pertama. (Disertasi doktor yang tidak diterbitkan) PPs UPI, Bandung.

Moslehian, M.S. (2000). A Glance at Postmodern Pedagogy of Mathematics. Departemen Matematika, Universitas Ferdowsi University, P.O.Box 1159, 91775 Mashhad, Iran.

[Online].

Tersedia:http://www.cochise.edu/information/library/documents/A\%20GLAN CE\%20AT\%20POSTMODERN\%20PEDAGOGY\%20OF\%20MATHEMAT ICS.HTM

Neyland, J. (1996). Teachers' Knowledge: The Starting Point for a Critical Analysis of Mathematics Teaching. Philosophy of Mathematics Education Newsletter 9. [Online]. Tersedia: http://www.people.ex.ac.uk/PErnest/pome/ pompart4.htm

Vygotsky, L.S. (1978). Mind in Society. Cambridge, MA: Harvard University Press. 